\title{
Adopting Conservation Polices for Industrial Heritage Museums: A Case Study of the Railways Museum, Cairo Egypt
}

\author{
Shreen Mohamed Amin, Hosam Refai and Rasha Kamal
}

\begin{abstract}
The emphasis in this paper is on analyzing conservation policies for Museums of Industry's exhibition and collections. The challenges of preserving the industry collections rely on the significance of many of these objects that lie in their operation. During the twentieth century, there was a shift in the practice and philosophy of museum conservation towards a more scientific approach that seeks to understand the chemistry of materials. ${ }^{1}$ Simple conservation and care procedures of the collections may seem obvious but analyzing the development of procedures for preservation and protection is provided vision, context, and content to such aspects of work at museums. The goal of preserving the museum collection is to preserve and manage the collection for scientific study, exhibition, programming, and education. ${ }^{2}$ The paper sheds light on the ethical responsibility of the museum where industry collection should be protected, unencumbered, cared for, and preserved. ${ }^{3} \mathrm{Also}$, it presents the Railways Museum in Cairo as a case study and highlights the appropriate measures that ensure the safety and security of the industry collections. Then, the paper develops a plan for the conservation of the industrial collections in museums that regarded very differently, due to numerous characteristics of conservation methods, challenges, and the changing nature of such kind of heritage.
\end{abstract}

\section{Key Words}

Challenges -Conservation- Industry Collections- vision

\section{Inroduction}

Measures for conserving the Industrial collection depend on the preservation of the functional integrity of such kind of heritage. Collection related to the industrial period is now changing, that there is an urgent need for a museum to conserve, preserve, and study the industrial collection that has had to be relocated from its original location. Moreover; the museums tell the story of the industrial cultures and their landscape. TICCIH charter sheds the light on such measures that could prevent the destruction or the removal of the industrial components of the sites where the value of an industrial site may be greatly reduced if in situ machinery and objects are removed or destroyed ${ }^{4}$. These Measures require a thorough knowledge of the various industrial processes which may have taken place in the industrial sites. The various industrial processes include all the former uses that should be examined and assessed. TICCIH charter states the possibility of the rehabilitation and possible adaptation of an industrial site to ensure its conservation, and this possibility is not accepted if the site has an especial historical significance where the original patterns of circulation and activity of such kind of heritage should be respected. TICCIH charter highlights the importance of conserving the human skills that involved in many industrial processes that should be carefully recorded and transmitted to younger generations. ${ }^{5}$

\footnotetext{
1 Friedrich Rathgen, Augustus Auden George, and Allden Auden Harold,the Preservation of Antiquities: A Handbook for Curators (Cambridge: Cambridge University Press:1905) 56

2 Gail Dexter Lord, Barry Lord, Collections management. The Manual of MuseumPlanning, 2nd ed, (London: AltaMira Press: 1999), 109-139.

3 American Association of Museums, Code of Ethics for Museums (Washington, D.C.: American Association of Museums, 2000). June 28,2019 http:// ww2.aam-us.org/resources/ethics-standards-and-best-practices/collections-stewardship

4. TICCIH The Nizhny Tagil Charter for the Industrial Heritage (Moscow, 2003), 1- 4, https://www.icomos.org/18thapril/2006/nizhny-tagil-charter-e. $\underline{\mathrm{pdf}}$

5. TICCIH is the world organization for industrial heritage. Its purpose is to promote preservation, conservation, investigation, documentation, research, and interpretation of the archaeology and the cultural heritage of the industry. TICCIH is ICOMOS' adviser on industrial heritage.
} 


\section{Methodology}

The study depended on primary fieldwork data extracted through, observation and semi-structured interviews. The interviews were directed to the staff of the Railway Museum to define the current conservation policy for Industrial heritage .Questions were designed to define the ways of interpreting and conserving the industrial collections at Railways Museum Cairo, focusing on the meaning of machine as knowledge embodied ${ }^{6}$ Answers defined the care and conservation policy approved bythe Foyptian Ministry of Transportation that meets ethical commitments and legal requirements.

The results of the interviews concluded that there is no conservation or restoration department in the Railways Museum: however, the museum staff conserves the objects by the display that guarantees the stability of the object, ${ }^{7}$ if anything happens to any device, they just deliver the device to the Egypt Transportation Authority; the new display is caring for the objects. Also, the curators of the museum are the ones in charge of caring for the objects. The museum is facing the problem of conserving the machines and the industrial structures where there are no specialists in the field of technical objects that may have to deal with all manner of materials combined in a wide variety of ways. Thus, the Railway Museum in Egypt needs Long-term daily maintenance and regular care among industrial circles. Developing management policies for the industrial heritage collection of the Railways Museum in Cairo is ensuring the balance of protection, preservation, and conservation. The management involves more than dealing with the protection and conservation of the industrial heritage collection itself; it also encompasses the value of such kinds of collections.

\section{Principles of conservation practices of museum objects}

Key conventions related to the preservation and protection of cultural heritage state the museum's preservation policy. The International Gharters for Conservation and Restoration described the principles of conservation practices of a museum object, 40 Years after the Venice Charter. ${ }^{.}$The starting point of all reflections on principles of preservation is the Venice Charter that describes some principles of conservation/preservation accepted in theory and practice. ${ }^{.}$The Nara Document highlighting modern conservation theory, tried to define the "test of authenticity in design material and workmanship" which is developed for the implementation of the World Heritage Convention of $1972 .{ }^{\circ}$ The 1954 Hague Convention provides measures regarding the protection of movable cultural heritage belonging to the museums. Article 19 of the Hague Convention provides a more detailed regulation of the protection of cultural property. ${ }^{.1}$

\section{Preventive conservation in museums}

Preventive conservation of a museum object is defined as "actions are taken to minimize or slow the rate of deterioration and to prevent damage to collections; includes activities such as development and implementation of guidelines for continuing care and use, risk assessment, , appropriate environmental conditions for exhibition and storage, and proper procedures for transport, packing, handling, and use. ${ }^{12}$ The two broad categories of preserving the physical and aesthetic condition of a museum object are both stabilization and restoration. ${ }^{13}$ Stabilization is a treatment action that is followed to increase the stability or durability of an object when an object has deteriorated to the point where it is in danger of being completely lost. Restoration is a treatment action that is followed in an attempt to bring an object as close as possible to its original appearance, and/or by replacing missing elements. ${ }^{14}$ Also, preventive conservation of a museum object includes recording and monitoring levels of
environmental agents (e.g., light, temperature, , relative humidity), controlling environmental agents inspecting and recording

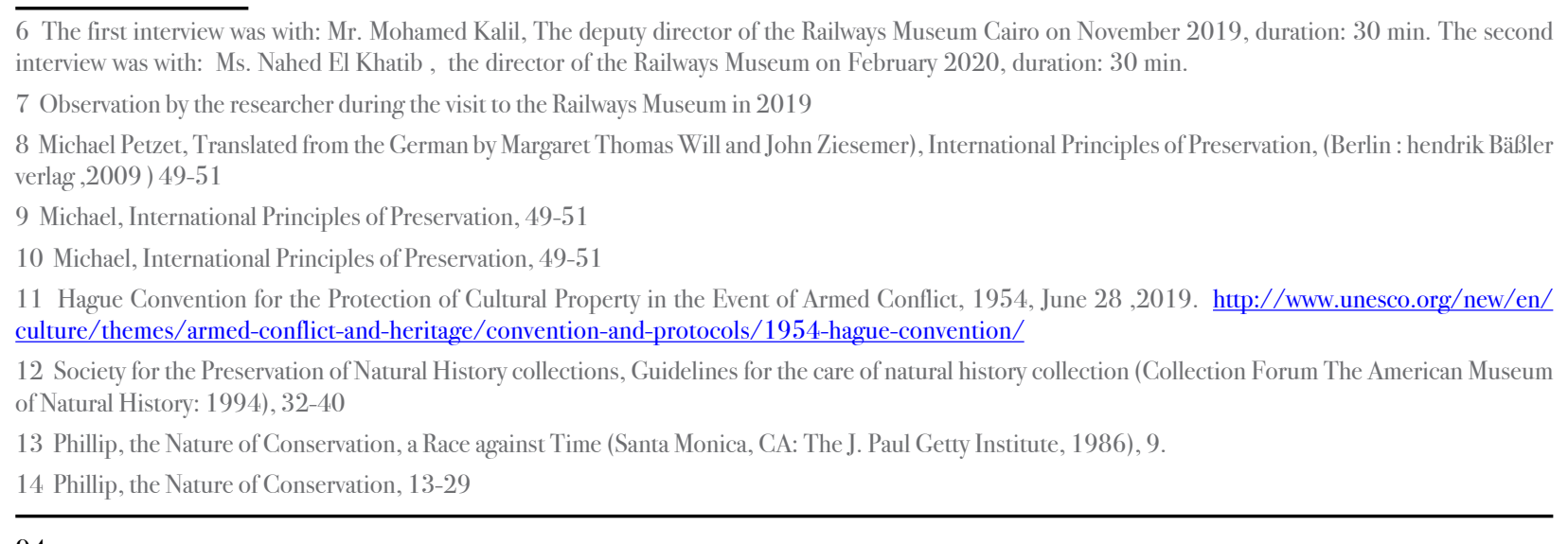

the condition of objects, establishing an integrated management program in all spaces housing museum collections, practicing proper, storage handling, exhibit, and packing techniques, incorporating needed information and procedures regarding the museum collection in emergency management plans. ${ }^{15}$

\section{Measures and actions of preventive conservation}

In preventive conservation, handling, storage, and management of collections (including emergency planning) are critica elements. The methodology sheds the light on how to apply preventive conservation measures effectively where the materials identification is one of the key aspects. ${ }^{16}$ The materials identification aims to prevent corroding or decaying of the objects; thus preventive conservation can be defined as any measure that reduces the potential for or prevents damage. ${ }^{17} \mathrm{Moreover}$, it is the effort to preserve, and the need to reveal and investigate the object and its values that can be understood as conservation. ${ }^{18} \mathrm{Chris}$ Caple states in his book, Conservation Skills, that there are procedures of caring and protecting the museums' objects agains the threat of physical damage, thus the physical risk of damage from handling (dropping) or moving the object is the mos obvious threat. Caple utilizes the role of a curator or conservator who can develop to minimize damage to objects. ${ }^{19}$ During the 20th century, scientific knowledge utilizing preventive conservation was increased; thus, specialist skills, materials, and equipment of museum collection became available effectively. ${ }^{20}$

The appropriate measures that ensure safety and security are one of the major factors to be considered to conserve the museums' collections. Museums face several security challenges with their collections; thus the safety and security procedures can help museums provide an effective service in response. The factors that comprise collection security management in museums provide the framework of the security measures. The Security Commission of the Confederation of Fire Protection Association Europe (CFPA-E) has developed common guidelines for protecting the museums' collections ${ }^{21}$; the guidelines aim at facilitating and supporting protection and security for the museums' collections. The guidelines state the importance of museums as places of aesthetic visualization of cultural creativity, hhey have a special responsibility which is protecting the objects from a plethora of risks in the best possible way. The guidelines shed light on a museum's management plan that needs to

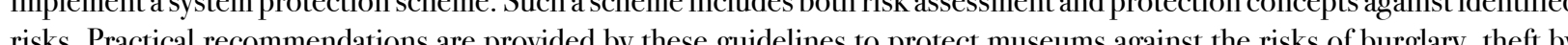
vis. visitors or employees, robbery, vandalism, fire, smoke and radiant heat, damage by natural hazards, and water. The guideline

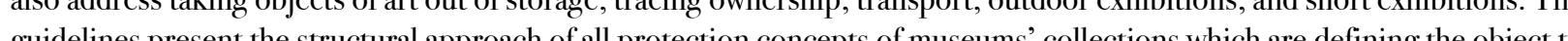
gitchines present section be protected and Trere (3)

\section{Concepts and practices of conserving industrial collections}

The conservation of industrial collections is focusing on the whole objects, their value, and their significance. ${ }^{24}$ The two main aims of conservation are limiting the rate of decay, because it leads to loss of information, and making objects physically an intellectually accessible to the visiors. The collections of museums vary greatly in nature and proportions in

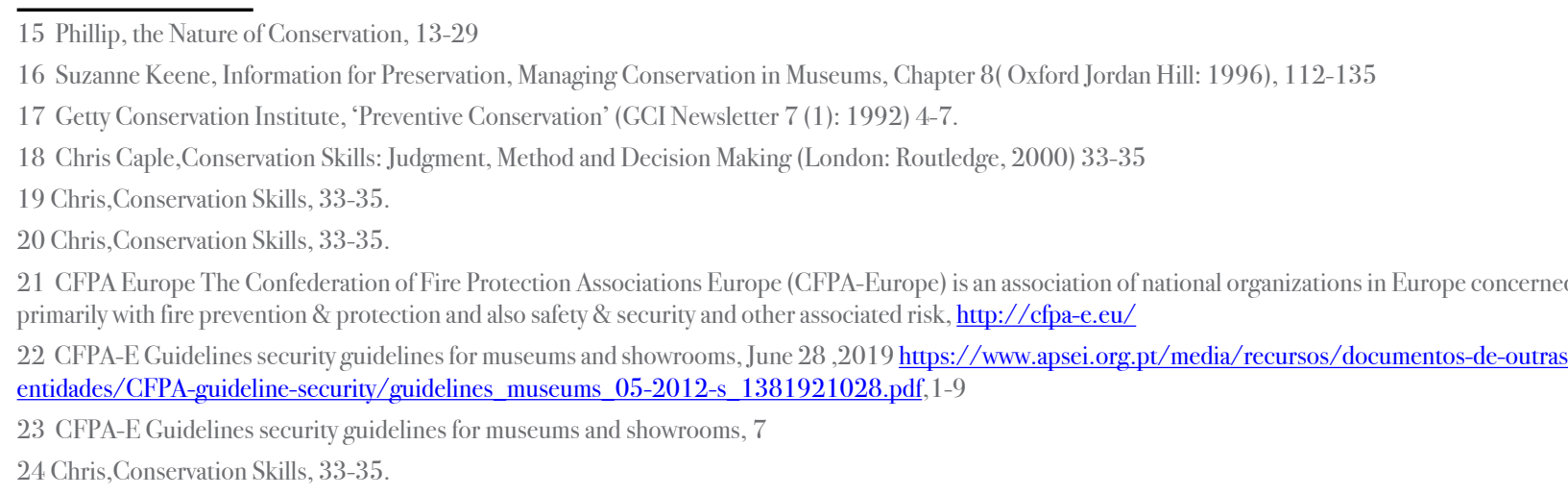


the amount of use they receive. ${ }^{25}$ The assessment of the condition of industry collection requires an understanding of materials and the causes and effects of deterioration, such kind of industry collection could be conserved by reconstructing missing features guided by the remaining evidence..$^{26}$ Industry collections are more than material objects they have meaning, value, and significance for the community. Such industry collections associated with people and events that accumulated different values. In the basic care of industrial objects, there are considerable material challenges. ${ }^{27}$ Industrial heritage collections are very large and with a special nature, need to be provided by a suitably preventive conservation environment: ${ }^{28}$ thus, assessing industrial heritage collections materials and conditions can be challenging. The mechanism and the way they function are the core of their significance. The technique of conservation used can pave the way to engage the visitors of the museums with the richness of industrial objects. Seeing industrial devices in a movement can reveal both the design and manufacturing skills; thus this might help to re-learn technologies used in such industrial objects. ${ }^{29}$

\section{Challenges of conserving industrial collections}

The challenges of preserving industrial collections rely on the significance of many of these objects that lie in their operation Considering the challenges in making industrial collections accessible is the basic care of industrial objects. Providing a suitably preventive conservation environment for industrial collections is one of such challenges; industrial collections are often highly complex and composite objects and made of a variety of substances metals, wood, textiles, lacquers, rubbers ,and plastics each with its problems. ${ }^{30}$ From a technical viewpoint, conservation and restoration techniques are important for maintenance. Many old machines and manufacturing techniques could be lost because of the lack of maintenance. Conservation helps in transferring the operating techniques that are also vital to keep the industrial objects in working condition. Conservation of industrial heritage requires recognizing and continually supporting the importance of conservation activities, avoiding the
incomplete maintenance that could damage the objects.

\section{The Railways Museum in Cairo}

The paper discusses the Railways Museum in Cairo analyzing the role of conservation in preserving both material and significance of industrial objects. The Railway Museum is a museum attached to Cairo's main railway station in Ramses Square. The museum was built in 1932, opened to the public in January $1933 .{ }^{31}$ The museum consists of two floors exploring the history of the railway since its establishment..$^{32}$ The museum was closed for renovation and then reopened to the public in 2016. The museum sheds light on the history of train transport in Egypt. The first major object one can see on arriving at the museum is a steam painted green locomotive. This early engine made by the British firm Robert Stephenson and Company for the Egyptian Railways in 1865 who was the son of the builder of the Stockton and Darlington Railway in the north of England in the $1820 \mathrm{~s} .{ }^{33}$ Figures $1-2$ show this early engine at the museum entrance. The early engine made by the British firm Robert Such an engine sheds light on the industrial heritage of Eoypt and the uses of Eoypt's early railways. The first floor of the museum displays early rolling stock and locomotives in addition to models of bridges and stations. One of the important models is an 1854 bridge that was the earlest Benha railway bridge in the Delta The models shed the light on the main Caino rilway (1928),

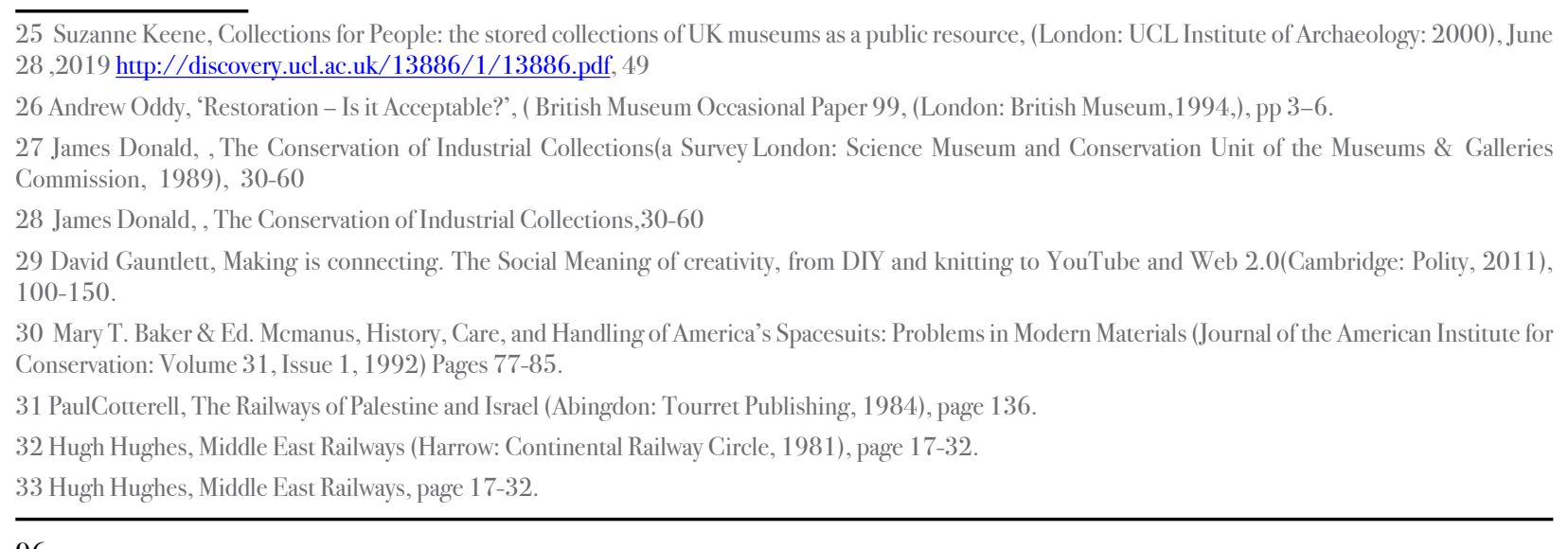

Cairo Saray Al-Qobba (1940), Alexandria Sidi Gaber (1948), and Port Said (1955) stations. ${ }^{34} F$ Figures3-4 show the display of the major objects on the ground floor. Figures 5- 7 show the display of the major objects on first floor Then, the second floor of the museum includes exhibits of the printing machines used to print tickets, primary models of trains, roval trains, steel bridges, and parts of a real train station.Figures8-10 show the display of the major industrial objects on the second floor.

\section{The Railways Museum collection}

Top floor

\section{Exhibit 1:}

\section{Model of joy valve gear:}

This model represents the steam distribution used for the engines of steam wagons at Birmingham-Yorkshire with three cylinders. This model was manufactured in ENR Boulac Workshops.

\section{Exhibit 2:}

This model of scale 1:2 shows the composition of the Walschaert Valve Gear. It includes a cylinder, piston, steam box divided by percentage to show the piston movement. The crank disc is marked in degrees to indicate the crank.

\section{Exhibit 3:}

Balance of copper to measure the size and thickness of the paper. It was used at the Press of the Egyptian Railways.

Exhibit 4:

Model of walschaert valve gear - 1844 :

This model shows the principle of the Walschaert Valve Gear; it includes a cylinder, piston, and valve chest, and piston valve. It has the crank which was marked in degrees to show the steam degree.

\section{Exhibit 5:}

Picture of a high - class AC coach which was first used in 1941

\section{Exhibit 6:}

Picture of a princesses' coach of the royal train

\section{Exhibit 7:}

\section{THE ROYALTRAIN- 1859}

Model of the khedivial train built-in EL-Qabbary workshops of the Eoyptian Railways in Alexandria .It was used by khedivia Ismail. The order of the coaches could be different from the real order. It consists of six coaches and one locomotive.

Hughes, Middle East Railways, page 17-32.

35 Observation by the researcher during the visit to the Railways museum in 2020 
The locomotive was built by R. Stephenson of Newcastle in 1859 and was equipped with water tanks that carried 700 gallons. It was elaborately decorated and maintained in that condition until 1887 when it was rebuilt for ordinary service.

> The first coach: It was a salon for officers, built by the Egyptian National Railways in 1868.The body frame is made from wood and covered with iron sheet panels. It was broken in 1929.

The second coach: is the princesses' coach built by Wright Co. in 1858. The under frame is built of iron with wooden headstocks fited with tanverse springs for a collision It is firnished inside wither fill blinds and its frame of green copper .It was scrapped in 1924.

The third coach is the khedivial salon, built by Mason \& Co. in America in 1858. It is elaborately ornamented both inside All windows and doors being fitted with pink silk curtains it consists of three compartments; each one has four mirs silver lamps. This salon is used until now as a Bacteriological coach.

$>$ The fourth coach is the "Family Saloon" built by Robert Stephenson in 1863. The under frame is of silk. The body framework is of wood. All windows are made of ebony wood. The trimmings are crimson and green silk. This coach was scrapped in 1928.

The fifth coach is also a "Family saloon” built by “Wright \& Sons in 1855 . The under frame is of silk with wood headstocks. The body framework is covered with "Papier-mâché" panels .This coach was scrapped in 1924.

The sixth and last coach is a "Royal Saloon" and was built by the Egyptian Railways in 1872. The insides trimmings are of buff leather and all doors and windows have pink silk curtains and the roof is of ebony wood. This saloon was scrapped in 1913.

\section{Exhibit 8:}

This model represents a map that shows the swing and fixed bridges related to the Egyptian Railways in Lower Egypt.

\section{Exhibit 9:}

Model of a fixed span of the bridge over the Nile at Edfina- 1932

The model shows the longest span ever built over the Nile in Egypt till (1932).This span consists of main girders that are of single lattice (V) type without end verticals.

\section{Renovation of the Railways Museum in Cairo:}

The renovation of the Railways Museum neglected the preservation of the original nature of the museum that dates back to the $19^{\text {th }}$ century, ruined the historic character of the museum; however, the new displaving method protects the nature of the industrial objects of the collection and the way they have displayed supports and empowers their conservation. Figures1 1-12 show the museum in 2012 during the renovation process where the original 1930s light fixtures as well as, the original floor tiles were removed.

\section{Conservation Polices of the Railways Museum in Cairo}

Conservation of the Railway Museum in Egypt focused mainly on the preservation of the museum's collection through the new display. The objects of the museum were a part of transporting activities in those days. Displaying such activities is one of the main factors in conserving Egyptian railway heritage. The new display is explaining why such industrial collections of the Railway Museum continue to be conserved. The conserving of the museum's collection utilizes the importance of industrial heritage as cultural property. The Railway Museum utilizes the importance of maintaining industrial objects by participating in special events; such events shed light on transportation technology. The museum presented a special exhibition in the international exhibition and conference for information and communication technology Cairo ICT 2018 which is an international exhibition, conference, and meeting place. The topic for ICT 2018 year was Driving Transformation. The exhibition presented the challenges. The interpretation of such objects requires a degree of interceptive treatment; the objects of such kind are operated to demonstrate their function; therefore, they need to be considered in the display and interpretation requirements. Figures 13-14 show the exhibition of the museum in Cairo ICT 2018.

\section{Developing a conservation plan for industrial Collections of the Railways Museum in} Cairo

The researcher presents a plan for the conservation of the industrial collection of the Railways Museum in Cairo that is regarded very differently, due to numerous characteristics of conservation methods, challenges, and the changing nature of such kind of heritage. The conservation plan considers challenges in the process of the conservation of industrial artifacts where technica objects have a practical function with characteristics that make them different. The plan is based on the recommendations of the meeting with the international governmental representatives of industrial heritage during the M CIMUSET $47^{\text {th }}$ annua conference, ICOM Kyoto 2019 has been held to identify the international approaches of interpreting and conserving the industrial heritage in museums. ${ }^{36}$ Figures 15-16 show the proof of attendance.

\section{The Conservation plan is based on the following aspects:}

1- Defining the conservation needs of the industrial collection as a whole in the Railways Museum , Cairo

2- Identifying priorities to set the relevant conservation practices.

3- Working to develop written conservation plan with the assistance of qualified conservator

4- Setting strategy for the long-term care of the industrial collection at the Railways Museum , Cairo

5- Defining the museum environment elements such as light, temperature and relative humidity, pollutants, pests

6- Increasing revenue to support the conservation strategy

\section{Care and conservation plan template}

\begin{tabular}{|l|l|l|l|l|}
\hline \multicolumn{4}{|l|}{ Railways Museum, Cairo (Data sheet) } & \\
\hline $\begin{array}{l}\text { Conservation } \\
\text { n e e d s }\end{array}$ & $\begin{array}{l}\text { Assessing industrial } \\
\text { collection materials } \\
\text { \&condition }\end{array}$ & $\begin{array}{l}\text { Defining highly } \\
\text { complex and } \\
\text { composite objects, }\end{array}$ & $\begin{array}{l}\text { Recording } \\
\text { collection with } \\
\text { a variety of } \\
\text { substances metals, } \\
\text { wood, textiles, } \\
\text { lacquers, rubbers } \\
\text { and plastics }\end{array}$ & $\begin{array}{l}\text { Analyzing the } \\
\text { challenges in } \\
\text { making working } \\
\text { industrial object } \\
\text { accessible }\end{array}$ \\
\hline Priorities & $\begin{array}{l}\text { Conserving the } \\
\text { mechanism of industrial } \\
\text { objects and the way they } \\
\text { function }\end{array}$ & $\begin{array}{l}\text { Defining the ways } \\
\text { to operate industrial } \\
\text { objects to bring them } \\
\text { back to life }\end{array}$ & $\begin{array}{l}\text { Finding the ways to } \\
\text { engage visitors with } \\
\text { these objects }\end{array}$ & $\begin{array}{l}\text { Finding the ways } \\
\text { to increase the } \\
\text { revenue }\end{array}$ \\
\hline
\end{tabular}

\section{Egypt's Government Ministries in charge of implementing the conservation plan}

The Egyptian Ministry of Trade and Industry, The Ministry of Culture of Egypt, The Egyptian Ministry of Tourism \&Antiquities, Arab organization for Industrialization, Egyptian National Railways Authority, The Ministry of Higher education and scientific research (Faculties of engineering)

Increasing revenue to support the conservation strategy is one of the main aspects of the conservation plan of the Railways

36 CIMUSET is the International Committee for Museums of Science \& Technology in ICOM, the International Council of Museums,September 2,201 http:///archives.icom.museum/internationals.html\&hthp://network.icom.museum/cimuset

2019. https://icom-kyoto-2019.org. 
Museum, Cairo. The researcher presents a sample of a project proposal, project charter, and stakeholder list; the sample aims to define the opportunities that could generate revenue. Figures 17-18show the museum Cafeteria and the gift shop

\section{Sample of a project proposal, project charter, and stakeholder list}

\section{Project Name}

(Producing industrial \& technical heritage models inspired by the collection of Railways Museum in Cairo)

\section{Current Position:}

The Railway Museum, Cairo has an excellent collection of items that could be lent to be used as the subjects of industrial models.

\section{SWOT Analysis}

\begin{tabular}{|c|c|}
\hline Points of Strengths & $\begin{array}{l}\text { 1-Excellent industrial collection such as models of } \\
\text { the first locomotives used in Egypt in addition to } \\
\text { bridges and stations as a way of interpreting the } \\
\text { status of transportation in Egypt. The museum has } \\
\text { a collection of several distinguished railway bridges. } \\
\text { One of the important models is an } 1854 \text { bridge that } \\
\text { was the earliest Benha railway bridge in the Delta. } \\
\text { The models shed the light on the main Cairo railway } \\
\text { station in Ramses Square, built- in 1893, in addition } \\
\text { to detailed models of other stations. } \\
\text { 2-An existing shop that has a good reputation among } \\
\text { the visitors }\end{array}$ \\
\hline Points of Weaknesses & $\begin{array}{l}\text { 1-Limited financial resources } \\
\text { 2-The market approach of the museum is not well } \\
\text { defined }\end{array}$ \\
\hline Opportunities & $\begin{array}{l}\text { 1-The gift shop of the museum is near the Ramses } \\
\text { Station where many families and diverse Egyptians } \\
\text { travel across Egypt. } \\
\text { 2-The Railway authority in Egypt, the governmental } \\
\text { body in charge of the museum has a separate } \\
\text { independent budget, and the industrial models } \\
\text { inspired by the museum collection could increase the } \\
\text { promotion of the museum shop }\end{array}$ \\
\hline Threats & Possible cuts in funding \\
\hline How to counter the threats & explore other avenues for funding and revenue sources \\
\hline
\end{tabular}

\section{Project Description:}

The aim of the project is to produce industrial and technical heritage models inspired by the collection of the Railways Museum in Cairo; the models would be sold for approximately $\$ 5.95$ including GST

\section{Project Objectives:}

1- Increasing revenue to support the conservation strategy

2- Raising the awareness of the value of the Egyptian industrial heritage; so that this awareness would be the means to increase understanding of the industrial past and present

4- Documenting the performance and value of the industrial heritage devices

5- Engaging a diverse community at the Railways Museum in Cairo.

\section{Project Market analysis}

\begin{tabular}{|l|l|}
\hline Competitor analysis & $\begin{array}{l}\text { The Railways authority, the government body in charge of } \\
\text { the project will support the idea because producing such } \\
\text { kind of industrial heritage models is a new initiative in } \\
\text { the Egyptian market }\end{array}$ \\
\hline Target market & $\begin{array}{l}\text { Museums visitors among the passengersin Ramses station } \\
\text { including the diverse communities of the Egyptian society }\end{array}$ \\
\hline Research & $\begin{array}{l}\text { Tourism research done by the Railways authority on the } \\
\text { official website of Transportation authority shows that } \\
\text { Foreign passengers are increasing in Ramses station, and } \\
\text { that's where the museum is located. }\end{array}$ \\
\hline
\end{tabular}

\section{Marketing}

\begin{tabular}{|l|l|}
\hline Marketing communications objectives & $\begin{array}{l}\text { Establish awareness of the new range of industrial } \\
\text { heritage models among target markets. ・ Encourage } \\
\text { industrial heritage models over the internet. } \\
\text { the Railways Museumforce }\end{array}$ \\
\hline Strategies & Raising awareness among visitors to the Railways museum \\
\hline Tactics & $\begin{array}{l}\text { Have the industrial heritage models available for sale on } \\
\text { the e-commerce section of the museum's website. } \\
\text { Publishinga newsletteron thehistory yof industrial heritage } \\
\text { in Egypt, then focusing on the history of transportation in } \\
\text { Egypt and the devicesused. } \\
\text { Launch a website on the industrial heritage in Egypt to be } \\
\text { a part of the website of the governmental transportation } \\
\text { authority }\end{array}$ \\
\hline Budget & $\begin{array}{l}\text { Models and actual copy designs of the exhibited objects } \\
\text { would be made for example a copy of the famous train } \\
\text { displayed in the museum. These copies would be sold } \\
\text { better and faster, as they are related to the display, than } \\
\text { regular unrelated models of no historical importance or } \\
\text { value. }\end{array}$ \\
\hline Evaluation & $\begin{array}{l}\text { Record numbers of the museum website visitors. Listing } \\
\text { the visitors' opinions }\end{array}$ \\
\hline
\end{tabular}


dopting Conservation Policesfor Industrial Heritage Museums:A Case Study of the Railuays Museum, Cairo Egyph

\section{Roles and responsibilities}

Project manager - leads the project. • Photographer - takes photos of items. • Marketing assistant - develops and implements promotional campaign, Coordinates the design and production of industrial models. $\bullet$ Website administrator - adds industrial models range to website and submits the industrial models samples to search engines, $\bullet$ Volunteer co-coordinator - liaises with Friends, hire a company to evaluate the impact of the projec.

\section{Evaluation}

Get feedback from museum visitors - include awareness of and reaction to the industrial models in visitor surveys.

\section{Timing and next steps}

\section{Approval from the finance section (February)}

- Copyright clearances for industrial heritage items (March) - Design and production of industrial models (March April) - Marketing campaign development (March April)

\section{Project charter}

\begin{tabular}{|l|l|}
\hline Project Name & $\begin{array}{l}\text { producing industrial \& technical heritage models } \\
\text { inspired by the collection of the Railways Museum in } \\
\text { Cairo }\end{array}$ \\
\hline Project Sponsor & $\begin{array}{l}\text { Egyptian Ministry of Trade and Industry \& the Railways } \\
\text { Authority, Egyptian Ministry of Transportation, the } \\
\text { ConservationSector at the Egyptian Ministry of Tourism } \\
\text { \&Antiquities }\end{array}$ \\
\hline Project description & $\begin{array}{l}\text { The Railways museum is currently pursuing a strategy } \\
\text { to increase revenue. The museum has an excellent } \\
\text { collection of items that could be lent to be used as the } \\
\text { subjects of industrial models. Such industrial models are } \\
\text { the perfect items for the museum gift shops }\end{array}$ \\
\hline Scope & $\begin{array}{l}\text { For producing interactive industrial heritage models } \\
\text { inspired by the Railways Museum collection, a detailed } \\
\text { study analyzes to such objects of the industry should be } \\
\text { performed, identifying their mechanism and value. The } \\
\text { study will be the duty of the Conservation Sector at the } \\
\text { Egyptian Ministry of Tourism\&Antiquities }\end{array}$ \\
\hline Business Case & $\begin{array}{l}\text { Interactive industrial heritage models inspired by the } \\
\text { Railways Museum collection to be one of the main } \\
\text { sources of income in the museum gift shop. The Railways } \\
\text { Museum is currently pursuing a strategy to increase } \\
\text { revenue. The museum has an excellent collection of } \\
\text { items that could be lent to be used as the subjects of } \\
\text { industrial models. Such industrial models are the perfect } \\
\text { items for the museum gift shops }\end{array}$ \\
\hline
\end{tabular}

\begin{tabular}{|l|l|}
\hline Priority order & $\begin{array}{l}\text { Approval from finance section (February) } \\
\text { - Copyright clearances for industrial heritage items } \\
\text { (March) }\end{array}$ \\
$\begin{array}{l}\text { Design and production of industrial models (March } \\
\text { April) } \\
\text { - Marketing campaign development (March April) }\end{array}$ \\
\hline Project deliverables & $\begin{array}{l}\text { - increase the revenue of the Railway Museum } \\
\text { - raise the awareness of the Egyptian community to } \\
\text { appreciate the value of the industrial heritage } \\
\text { - engage the Egyptian community with the history of } \\
\text { industrialization in Egypt } \\
\text { - Increasing revenue to support the conservation } \\
\text { strategy }\end{array}$ \\
\hline Benefits & $\begin{array}{l}\text { KPI Measuring results \& indicator for measuring the } \\
\text { state of conservation of industrial heritage objects of the } \\
\text { Railway Museum and the producing industrial models }\end{array}$ \\
\hline Steering committee & $\begin{array}{l}\text { - Members of Administration of the Railway Museum, } \\
\text { Cairo }\end{array}$ \\
\hline Key stakeholders & $\begin{array}{l}\text { Central government } \\
\text { - Egypt Railways Authority } \\
\text { - Administration of the Railway Museum }\end{array}$ \\
\hline Risks & If the produced industrial models are poor products. \\
\hline Comments & $\begin{array}{l}\text { The project is under the umbrella of the Egyptian } \\
\text { Central government }\end{array}$ \\
\hline
\end{tabular}

\section{Stakeholders' list}

A stakeholder in the project can be defined as a person or organization that has the right and capacity to participate in producing industrial \& technical heritage models inspired by the collection of Railways Museum in Cairo. In this case, the stakeholders are Central government

Egypt Railways Authority

Administration of the Railway Museum

The restoration sector of the Ministry of Tourism \& Antiquities

The Egyptian Ministry of Industry

Marketing Department, Egyptian Ministry of Information- Media Reporting and disseminating information about the industrial heritage protection

Travel agencies

Tourism investment company

Expert group providing intellectual support for the protection of industrial heritage

Local residents- Tourists 


\section{Conclusion}

The results deduced the importance of defining the conservation needs of the museum's industrial collections; conserving the industrial collection is dealing with some of the practical and ethical issues. If we could preserve the old machine, we can preserve the history and memories of people who were involved in the working of such mo hines In the case of the Railways' Museum, Cairo, the conservation plan defines the priorities to set the relevant conservation practices. Setting strategy for the long-term care of the industrial collection is linked with the revere- generating that sup pors

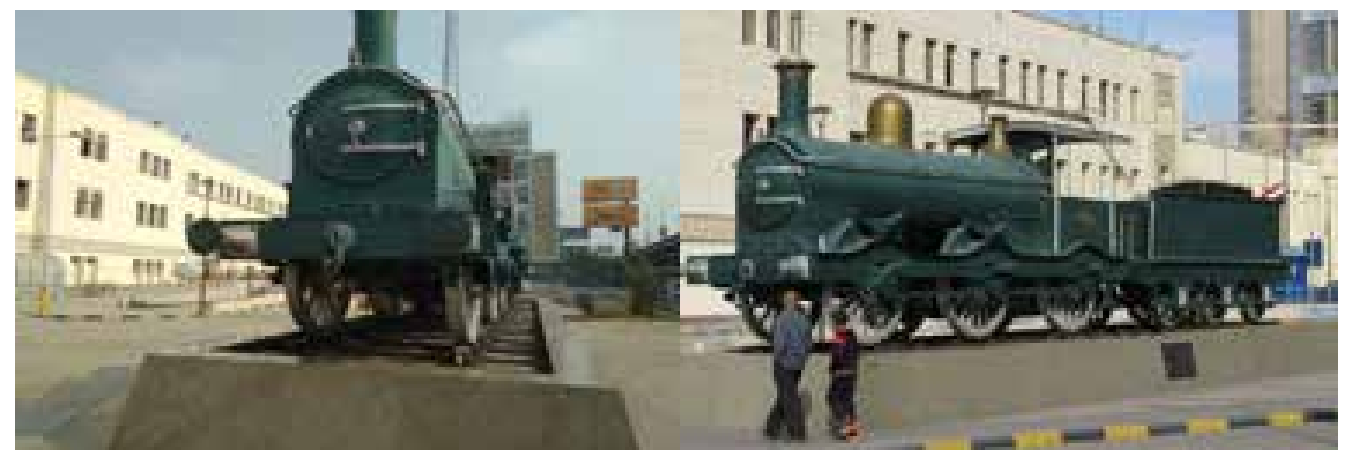

Figure 1-2show the early engine a the museum entrance OShreenMohamedAmin July 28, 2019

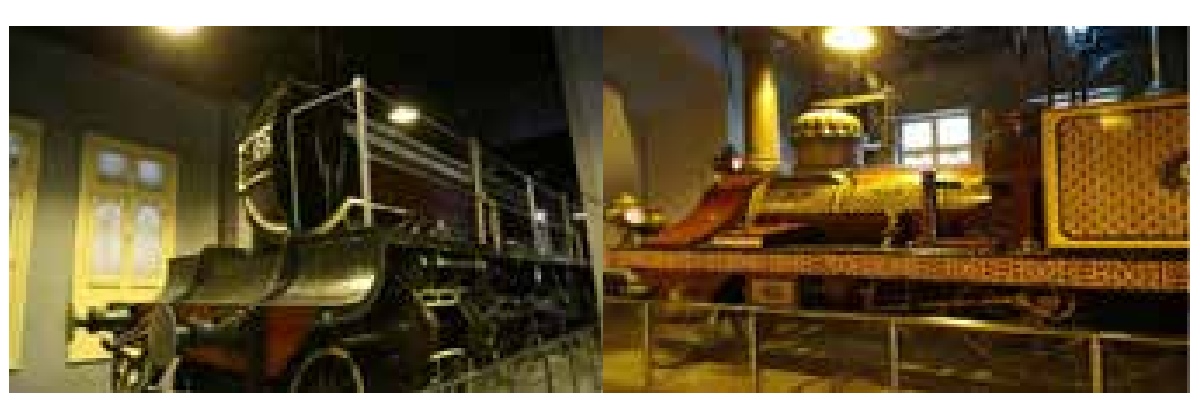

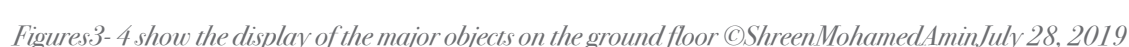

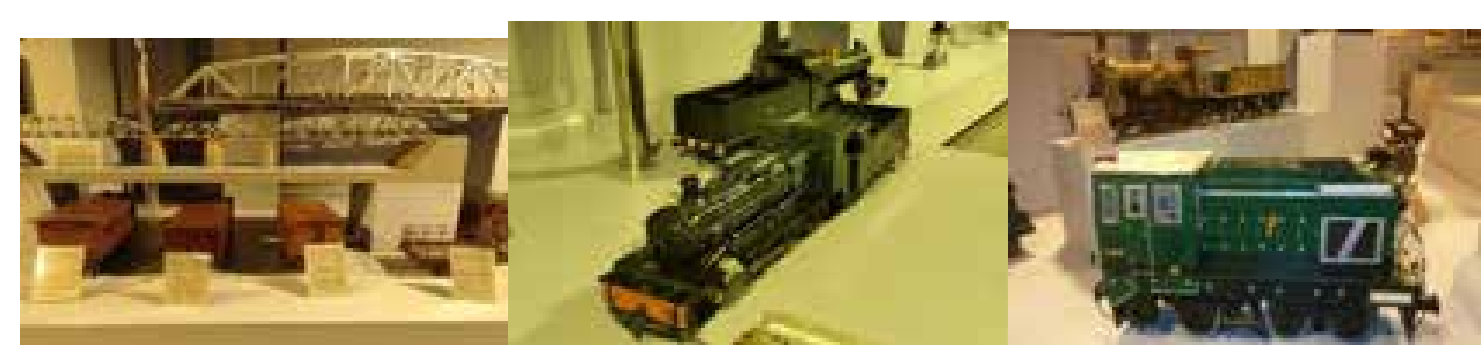

Figures5-7show the display of the major objects on firsstfloor OShreen MohamedAmin July 28, 2019

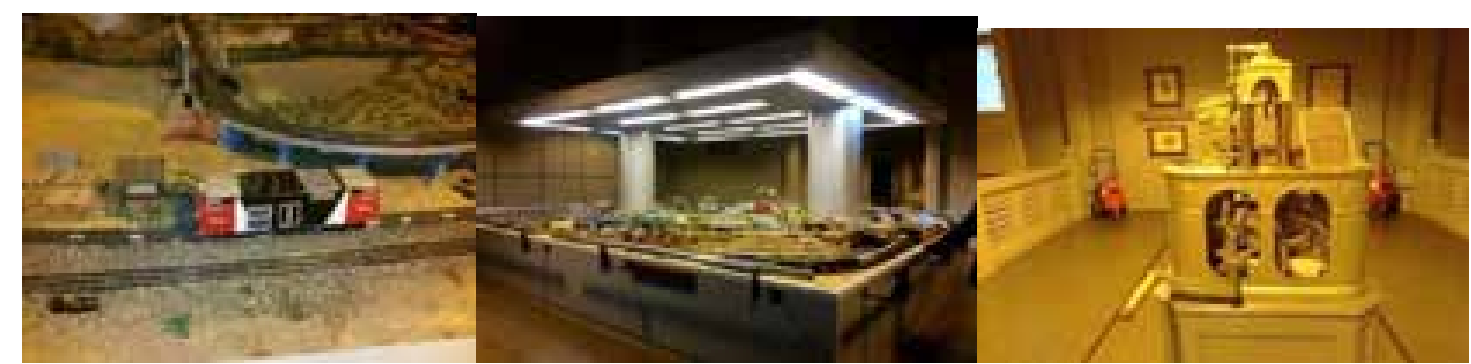

Figures \& 10 show the display of the major objects on second floor OShreenMohamedAminJuly 28, 2019 


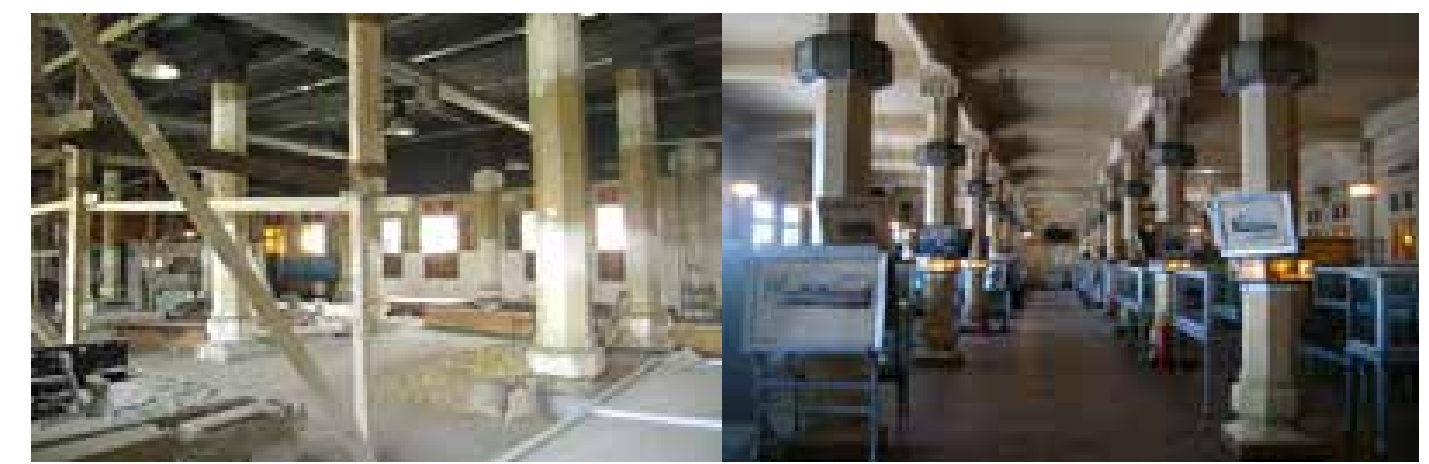

Figures I 1-12 show the museum in 2012 during the renovation process: Author Cairo observer photographed in 2009, before renovation, accessed March 3,2020 htpps://cairobserver.com/post/30117632943/is-cairos-railway-museum-lostt.XRYayOszbIU

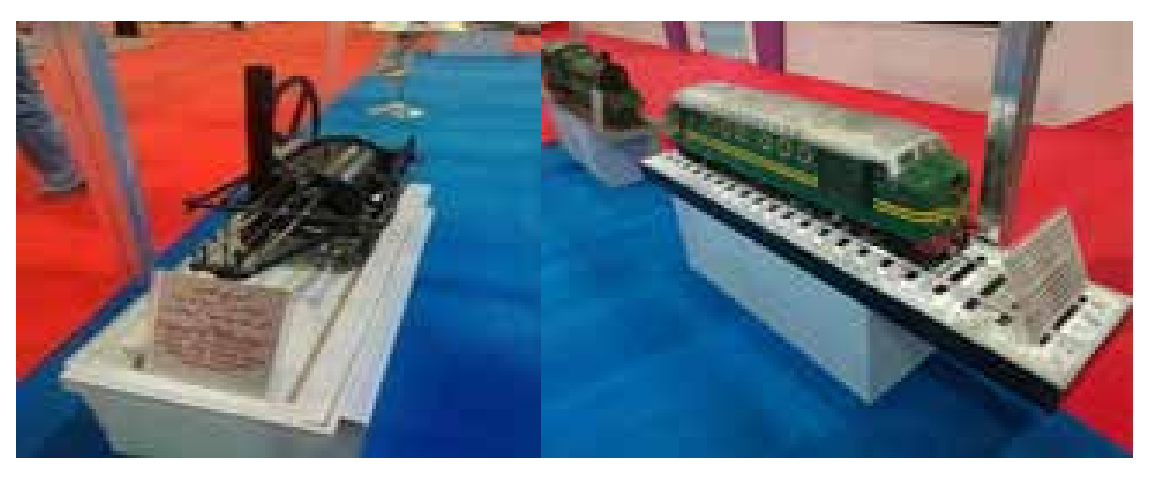

Figure 13-14 shous she exhibition of the museum in Cairo ICT 2018. Sautrday, February 10, 20180ShreenMohamedAmin

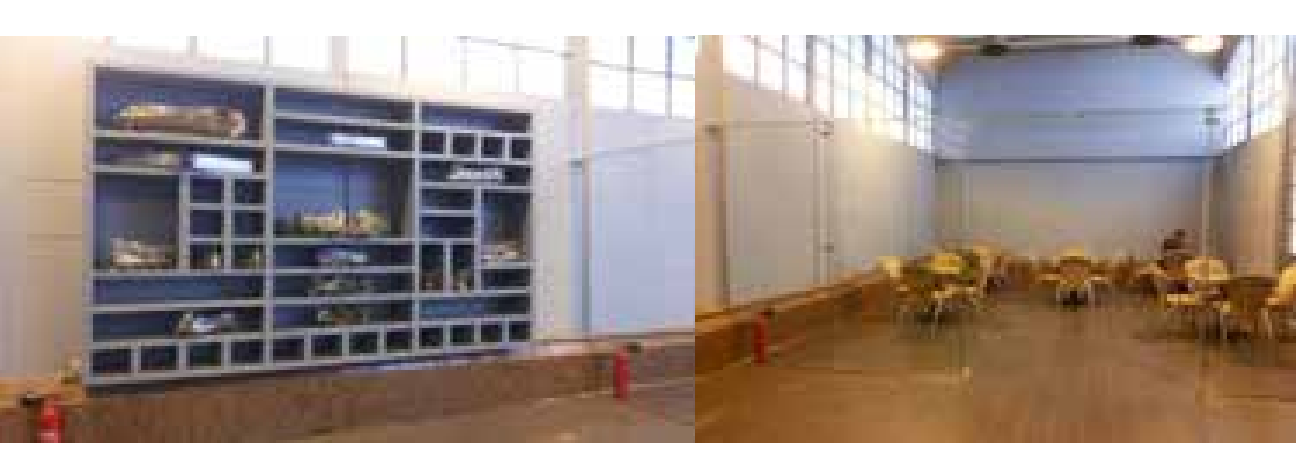

Figures 15-16. show the museum Cafeteria and the gift shop\&:OShreenMohamedAmin July 28, 2019

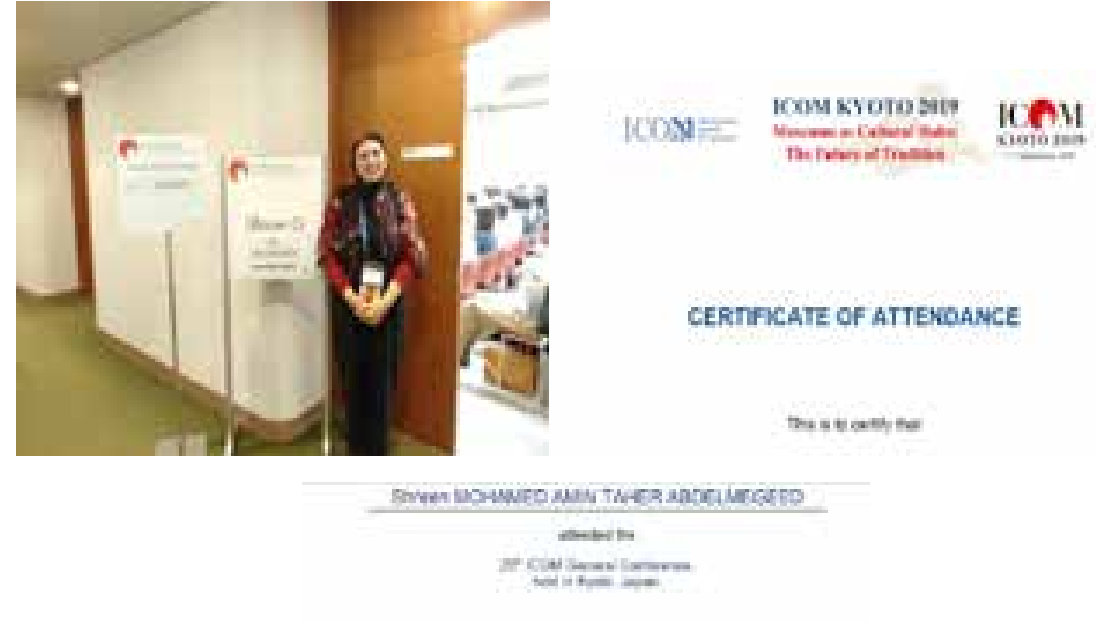

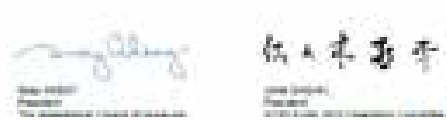

Figures 7 shous the proof of attendance ICOM 25th General Conference Kyoto, Japan, 2019@ShreenMohamedAmin 


\section{Bibliography:}

- American Association of Museums, Code of Ethics for Museums (Washington, D.C.: American Association of Museums, 2000). June 28,2019 http://ww2.aam-us.org/resources/ethics-standards-and-best-practices/collectionsstewardship

- Caple Chris.Conservation Skills: Judgment, Method and Decision Making (London: Routledge, 2000) 33-35

- CFPA-E Guidelines security guidelines for museums and showrooms. June 28 ,2019 https://www.apsei. org.pt/media/recursos/documentos-de-outras-entidades/CFPA-guideline-security/guidelines_museums 052012-s 1381921028.pdf

- Cotterell Paul. The Railways of Palestine and Israel (Abingdon: Tourret Publishing, 1984). page 136.

- Donald James. The Conservation of Industrial Collections (a Survey London: Science Museum and Conservation Unit of the Museums \& Galleries Commission, 1989). 30-60

- Dexter LordGail. Lord Barry. Collections management. The Manual of Museum Planning, 2nd ed, (London: AltaMira Press: 1999). 109-139.

- Getty Conservation Institute. 'Preventive Conservation' (GCI Newsletter 7 (1): 1992) 4-7.

- Gauntlett David. Making is connecting. The Social Meaning of creativity, from DIY and knitting to YouTube and Web 2.0(Cambridge: Polity, 2011).100-150

- Hague Convention for the Protection of Cultural Property in the Event of Armed Conflict, 1954, June $28,2019$. http://www.unesco.org/new/en/culture/themes/armed-conflict-and-heritage/convention-and-protocols/1954-

hague-convention/

- Hughes Hugh. Middle East Railways (Harrow: Continental Railway Circle, 1981), page 17-32.

- Keene Suzanne. Collections for People: the stored collections of UK museums as a public resource.(London: UCL Institute of Archaeology: 2000), June 28 ,2019 http://discovery.ucl.ac.uk/13886/1/13886.pdf, 49

- Keene Suzanne. Information for Preservation. Managing Conservation in Museums. Chapter 8( Oxford Jordan Hill: 1996), 112-135

- Oddy Andrew. 'Restoration - Is it Acceptable?', ( British Museum Occasional Paper 99, (London: British Museum,1994,), pp 3-6.

- Petzet Michael. Translated from the German by Margaret Thomas Will and John Ziesemer), International Principles of Preservation. (Berlin : hendrik Bäßler verlag ,2009 ) 49-51

- Rathgen Friedrich. Auden George Augustus. and Auden Harold Allden.the Preservation of Antiquities: A Handbook for Curators (Cambridge: Cambridge University Press:1905) 56.

- Society for the Preservation of Natural History collections. Guidelines for the care of natural history collection (Collection Forum The American Museum of Natural History: 1994). 32-40

- T. Baker Mary \& Mcmanus Ed. History, Care, and Handling of America's Spacesuits: Problems in Modern Materials (Journal of the American Institute for Conservation: Volume 31, Issue 1, 1992) Pages 77-85.

- TICCIH The Nizhny Tagil Charter for the Industrial Heritage (Moscow, 2003),1- 4, https://www.icomos. org/18thapril/2006/nizhny-tagil-charter-e.pdf

- Ward Phillip R. the Nature of Conservation. a Race against Time (Santa Monica, CA: The J. Paul Getty Institute, 1986)

\section{Abbreviations}

- TICCIH the Nizhny Tagil Charter for the Industrial Heritage, the world organization for industrial heritage. Its purpose is to promote preservation, conservation, investigation, documentation, research and interpretation of the archaeology and the cultural heritage of the industry. TICCIH is ICOMOS' adviser on industrial heritage.

- CFPA Europe The Confederation of Fire Protection Associations Europe (CFPA-Europe) is an association of national organizations in Europe concerned primarily with fire prevention \& protection and also safety \& security and other associated risk

- CIMUSET is the International Committee for Museums of Science \& Technology in ICOM , the International Council of Museums,

- ICOM The International Council of Museums 